\title{
WASTEWATER PROJECT DEVELOPMENT OF TEHRAN
}

\author{
G. BADALIANS GHOLIKANDI ${ }^{1}$, H.R. URUMIEH ${ }^{2}$, E. DEHGHANIFARD ${ }^{3}$ \& R. RIAHI ${ }^{4}$ \\ ${ }^{1}$ Power and Water University of Technology/Water Research Institute, Tehran, Iran. \\ ${ }^{2}$ Pars Arianab Consulting Engineers, Esfehan, Iran. \\ ${ }^{3}$ Iran University of Medical Sciences/Water \& Wastewater Research Center, Water Research Institute, Tehran, Iran. \\ ${ }^{4}$ Water \& Wastewater Research Center, Water Research Institute, Tehran, Iran.
}

\begin{abstract}
Tehran, the capital city of Iran, has had many problems in the environmental field. Wastewater collection and treatment is one of most important of those. Tehran Sewerage Company has worked on the integrated wastewater management of Tehran by considering rapid population growth which results in increased water consumption and consequently more wastewater production. The wastewater project of Tehran began in 1959, but was stopped by the revolution in 1979. It was started again with financial support from the World Bank in 1990. This study conducted an environmental, social and financial assessment (short, medium and long term) of the Tehran Sewerage Project. Results showed that this project has moderate and temporary effects on environment and social communities. Furthermore, this paper proposes a management plan for mitigation measures (environmental monitoring and auditing). The combination of three solutions - governmental financial resources, public-private participation and the World Bank loan - as a function of three main factors - time, resources and quality - is discussed and investigated from an economic point of view. In this respect, supporting the private sector participation is considered as one of the critical factors for the success of the project.

Keywords: environmental effects, financial assessment, social effects, sewerage, Tehran Sewerage Company, wastewater.
\end{abstract}

\section{INTRODUCTION}

Sewerage is defined as 'a system of sewers and ancillary works to convey sewage from its point of origin to treatment works or other place of disposal'. A sewerage system is one of a number of vital public utilities on which the modern community is so dependent. Unfortunately, much of this work is not visible to the general public, and the absence of glamour often results in a lack of appreciation of its importance. Sewers (together with all the 'ancillary' works, including pumping installations) are designed to collect and convey both domestic and industrial waterborne wastes and surface water run-off. Foul sewerage design is based on the number and density of buildings, the number of families per building, the size of the family and the varying habits of the population as regards the use of water. For the adequate design of surface water sewers, an engineer must have knowledge of the topography, together with details of the intensities of rainfall in the particular district. There is an economic limit to the intensity of storm that can be catered for and, in practice, sewers are usually designed for the worst storm likely to occur every year or, in some cases, every five years. Various design methods for surface water sewers have been used in the past, but modern practice is to use either the 'rational' (Lloyd-Davies) formula or the Transport and Road Research Laboratory hydrograph method $[1,2]$.

Tehran city, the capital of Iran, is one of the most important metropolitan cities in the world, with an area of over $800 \mathrm{~km}^{2}$ and a population of about 11 million people; it has many problems with wastewater management [3]. One of these problems is the lack of conformity between the water supply facilities and the wastewater collection and disposal system, which covered $98 \%$ and $13 \%$, respectively, of the urban population in 2006. The ever-increasing development of Tehran, the greater centralization of the population in the city, the necessity for utilizing water resources from other watersheds and its transmission to the city, the pollution of water and soil in the urban zone due to incorrect and non-hygienic removal of sewage may all damage, seriously, the environmental body of the city of 
Tehran and result in the occurrence of unpleasant environmental phenomena. The important environmental issues associated with deficient sewerage network in Tehran are quality deterioration and contamination of groundwater resources and soil, public health threat due to increasing incidence of diseases, building destruction due to pedestal erosion by wastewater flows, lack of water resources for agricultural irrigation, etc. These problems call for a large executive operation, dynamic management, technical facilities and executive capacity, coordination between various city organizations and a considerable amount of financial resources supported by national urge and awareness.

\section{TEHRAN SEWERAGE PROJECT}

\subsection{Characteristics of Tehran}

Tehran is the capital and largest city of Iran; it is the administrative center of Tehran Province. Tehran is a sprawling city located at the foot of the Alborz mountain range. Tehran's climate is largely defined by its geographic location, with the towering Alborz Mountains to its north and the central desert to the south. It can be generally described as mild in the spring, hot and dry in the summer, pleasant in the autumn and moderately mild in the winter. As a large city with significant differences in elevation among various districts, the weather is often cooler in the hilly north than the flat southern part of Tehran. Summer is usually hot and dry with very little rain, but relative humidity is generally low. The majority of the light annual precipitation occurs from late autumn to mid-spring, but no specific month is particularly wet. The hottest month is July (mean minimum temperature $23^{\circ} \mathrm{C}$, mean maximum temperature $36^{\circ} \mathrm{C}$ ) and the coldest month is January (mean minimum temperature $-1^{\circ} \mathrm{C}$, mean maximum temperature $8^{\circ} \mathrm{C}$ ). Although, compared to other parts of the country, Tehran enjoys a moderate climate, weather conditions can sometimes be unpredictably harsh. The highest temperature recorded is $48^{\circ} \mathrm{C}$ and the lowest is $-20^{\circ} \mathrm{C}$ (Table 1). On 5 and 6 January 2008 , after years of relatively little snow, a wave of heavy snow and low temperatures shocked the city, covering it in a thick layer of snow and ice, forcing the Council of Ministers to officially declare a state of emergency and calling the following two days (6 and 7 January) off for the capital [4].

\subsection{Water consumption}

The annual consumption rate of water in Tehran was 70 million $\mathrm{m}^{3}$ in 1961. Nevertheless, in recent years, it has increased to $>800$ million $\mathrm{m}^{3}$. For the same reason and due to the discharge of about 500 million $\mathrm{m}^{3}$ of wastewater into Tehran's groundwater reservoirs, $>1$ billion $\mathrm{m}^{3}$ of the said groundwater reservoirs are polluted, which makes it impossible to enjoy the water resources existing in such a wide area. It should be noted that this matter may cause Tehran's groundwater reservoirs to increase beyond $1 \mathrm{~m}$, especially in the southern part of this city [5].

Table 1: Monthly normal high and low temperatures for three districts of Tehran.

\begin{tabular}{|c|c|c|c|c|c|c|c|c|c|c|c|c|c|c|}
\hline District & & Jan. & Feb. & Mar. & Apr. & May & Jun. & Jul. & Aug. & Sep. & Oct. & Nov. & Dec. & Annual \\
\hline \multirow{2}{*}{$\begin{array}{l}\text { Mehrabad } \\
\text { (southwest) }\end{array}$} & Max. & -0.4 & 1.2 & 5.4 & 11.2 & 16.1 & 20.9 & 23.9 & 23.3 & 19.3 & 13.3 & 6.7 & 1.7 & 11.9 \\
\hline & Min. & 7.9 & 10.4 & 15.4 & 22.1 & 27.9 & 33.9 & 36.6 & 35.6 & 31.6 & 24.4 & 16.2 & 10 & 22.7 \\
\hline \multirow{2}{*}{$\begin{array}{l}\text { Gisha } \\
\text { (center) }\end{array}$} & Max. & 0.8 & 2.1 & 5.7 & 11.6 & 15.9 & 21.8 & 25.0 & 24.6 & 20.5 & 14.4 & 7.5 & 2.9 & 12.7 \\
\hline & Min. & 6.9 & 9.2 & 13.4 & 20.3 & 15.9 & 21.8 & 34.5 & 34.1 & 29.8 & 22.9 & 14.6 & 8.9 & 21 \\
\hline \multirow{2}{*}{$\begin{array}{l}\text { Tajrish } \\
\text { (north) }\end{array}$} & Max. & -1.5 & -0.2 & 4.0 & 9.8 & 14.0 & 19.6 & 22.6 & 21.9 & 17.5 & 11.6 & 5.4 & 1.0 & 10.5 \\
\hline & Min. & 6.1 & 8.1 & 12.9 & 19.8 & 25.0 & 31.2 & 33.9 & 33.5 & 29.3 & 22.4 & 14.3 & 8.6 & 20.4 \\
\hline
\end{tabular}




\subsection{History of the sewerage project}

Preliminary studies of the Tehran Sewerage Project (phase 0) were undertaken by the United Nations Development Plan and the WHO in 1971. After that, in 1976, complementary studies of phase 1 and studies on collection of surface water were entrusted to the Tehran municipality. As continuation of studies was suspended due to occurrence of the revolution, the basics, particularly population, urban set-up and density and land use, underwent major changes. With a view to update the previous studies based on recent conditions, and to carry out studies on phase 2, the project was entrusted to the local consulting engineers in 1985 . The review of this project was completed and approved by the Tehran Regional Water Organization in 1986, after which studies for stage 2 was embarked upon. With the change of the client from Tehran Regional Water Organization to Tehran Water and Wastewater Company and taking into account the very high cost of carrying out the project, actions were taken to receive a loan from the World Bank, which again necessitated some amendments and modifications in the basics of phase 1. Due to numerous problems that arose as a result of unhygienic disposal of sewage and the need for rapid implementation of the project, checking of phase 1 studies and performing studies on phase 2 based on the changes already made was started in 1993. The project was approved in 1994. After the approval, preparation of the executive drawings was started [6].

The time lost has to be compensated for in a rather short time by overcoming a host of political, social, economic and cultural hurdles. Success in this direction demands efficient planning and management to overcome the obstacles in the way of attaining the project goals.

1. Qualitative objectives: Protection of the environment, promotion of public sanitary levels, preventing contamination of groundwater resources considered as a part of the water supply reservoirs, transferring the heavy costs of medical treatment to the low costs of disease prevention, expansion of green zones and clean air to improve public behavior in a delightful surrounding, preventing usage of raw sewage in irrigation, changing water consumption trends from a single wasteful cycle to a multiple and useful cycles, replenishing water beds around Tehran with effluents.

2. Quantitative objectives: Establishment of sewage collection pipeline network throughout Tehran for the entire project exceeding 9 million meters in an area of about 70,000 ha, construction of the required sewage treatment plants in appropriate sites for the entire project to serve a population of 10.5 million people, allocation and installation of over 875,000 connections to the subscribers for the entire project, construction of $76 \mathrm{~km}$ of sewage tunnels [7].

The major development objective of the proposed Tehran Sewerage Project is to improve the environmental conditions in Greater Tehran, with a present population of about 7 million. The objectives would be achieved through:

- provision of satisfactory wastewater collection and treatment facilities for about 2.1 million people, covering an area of about 16,500 ha;

- improvements in public health and reduction of surface and groundwater pollution;

- provision of treated wastewater for irrigation of about 15,000 ha on the Varamin plain;

- development of the Tehran Sewerage Company (TSC) into a fully autonomous entity to be operated on a commercial basis; and

- facilitation of private sector participation in the sector by contracting out various TSC functions such as engineering, construction supervision and operation and maintenance [7]. 
A development program has been prepared for the extension of wastewater collection and disposal facilities for Greater Tehran. The development is proposed to take place in five phases to cover the period until 2030. For phases 1 and 2 covering the periods up to 2006 and 2011, respectively, and a population of 4.2 million (about 2.1 million in each phase), wastewater treatment works will be constructed in the south of Tehran for the use of treated effluents in the Varamin irrigation system. For phases 3-5, covering a population of about 6 million, additional wastewater treatment works will be constructed southwest of Tehran with the extension of a separate tunnel/trunk main system [8].

The project covers, as shown in Fig. 1, the phase 1 requirements and consists of interceptors and laterals, two trunk mains - the western one to be laid as a pipe and the eastern one to be constructed

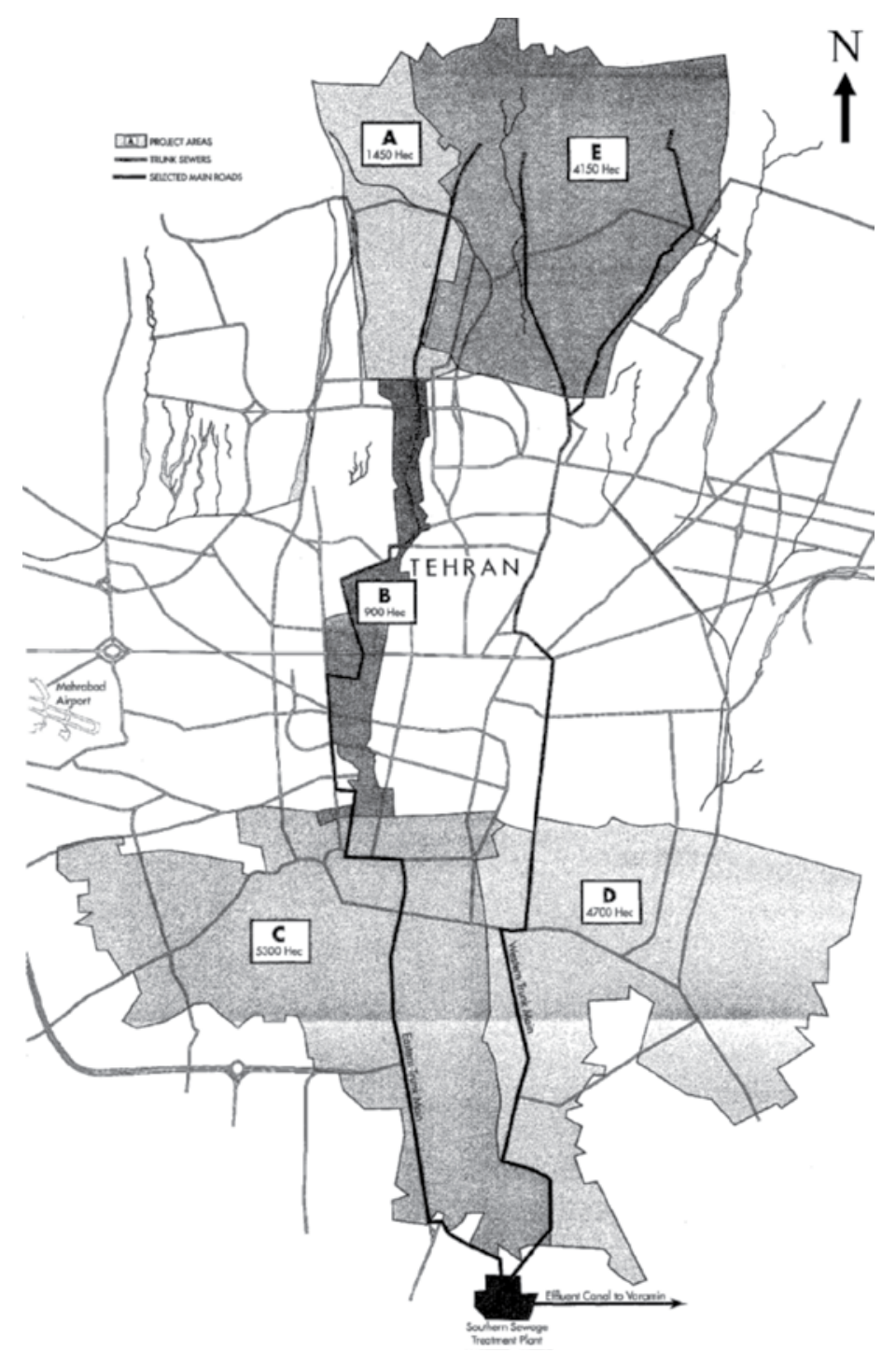

Figure 1: Layout of the Tehran Sewerage Project. 
as a tunnel - and the southern wastewater treatment works. Areas to be covered by a wastewater collection system are about 5,600 ha in the northern part of the city, about 10,000 ha in the southern part and about 900 ha in the central part. The project also includes operation and maintenance equipment and technical assistance/training/consultant services for institutional development and project management, engineering design and construction supervision, updating of the wastewater development program, and feasibility study and engineering design for phase 2 investments [9].

\subsection{Benefits and target population}

The benefits will include: (i) improved services for the urban population of Tehran, particularly, the low income groups living in the southern part of the city; (ii) a continuous and safe use of present groundwater sources for Tehran's water supply, which, in the long term, could be extended in pace with improved groundwater conditions; (iii) increased agricultural outputs through the use of treated effluents for irrigation and treated sludge for soil conditioning; (iv) a reduction in health risks due to improved sanitary and environmental standards; and (v) less damage to building structures by a lowering of the groundwater levels as a result of the provision of a centralized wastewater collection system. The project will, specifically, target the population in the south of Tehran. This population represents about $65 \%$ of the total population to be covered under the project $[10,11]$.

\section{MATERIALS AND METHODS}

\subsection{Environmental monitoring and auditing}

The objective of this environmental assessment is to identify negative environmental effects, if any, of the proposed project and to recommend mitigative measures to address such concerns.

It is proposed that the management unit of TSC develop mitigative measures under a management plan framework whose outline is presented here. Under this plan, it is ensured that the defined objectives of the Tehran Sewerage Project are achieved completely, preventing or minimizing any potentially adverse environmental impacts. Limitation of noise, odors, screenings disposal and visual impacts is the major target for disturbance minimization during implementation and operation period of the project. TSC is responsible for the implementation of the project while the Department of the Environment (DOE) is responsible for monitoring discharge into the environment and its effects to ensure that required standards are met and adverse impacts are minimized.

Where necessary, specialists such as other government departments, private companies or academic research institutions may carry out the sampling and analysis, but DOE will be responsible for overseeing their activities. DOE is obliged to conduct periodical sampling and analysis (weekly and monthly). The day of sampling should be chosen at random on a 7-day basis. Treated sludge disposed of to agricultural land for use as a fertilizer should be regularly monitored for compliance with DOE or Ministry of Agriculture (MOA) standards (for heavy metals in sludge and application rates). DOE and Food and Agriculture Organisation of the United Nations (FAO) will ensure that treated sludge is being stored for at least 1 year prior to its use on agricultural land. Soil in areas where effluents or sludge is used in agriculture will be periodically monitored for the heavy metals to ensure compliance with MAO standards. DOE and TSC will monitor the quality of Tehran's surface waters. This should reveal improvements in water quality and highlight any continuing pollution problems. The raw sewage inflow at the sewage treatment plant and the treated effluent will be regularly monitored by TSC for five-day biological oxygen demand, total suspended solids, total nitrogen, heavy metals, toxic materials, fecal coliforms and intestinal nematode eggs to assess performance. Spot samples will be taken once a day so that the operators can respond to any irregularities. Treated 
sludge disposed of to agricultural land for use as a fertilizer will be monitored for moisture content, $\mathrm{pH}, \mathrm{Cd}, \mathrm{Cr}, \mathrm{Cu}, \mathrm{Ni}, \mathrm{Pb}, \mathrm{Hg}$ and $\mathrm{Zn}$. The sampling program is a part of TSC project controlling system. If the effluent quality data show that the arithmetic mean number of nematode eggs is greater than the WHO guideline of one per liter, then TSC will have to provide suitable tertiary treatment with a proven ability to ensure compliance with the WHO guidelines. The decision whether tertiary treatment is necessary or not should be made on the basis of data from at least 1 year's operation. The effluent recharged on the South Plain will become part of the groundwater resources by the Tehran Regional Water Authority, which will establish a monitoring program to confirm that groundwater quality is not adversely affected. In addition, the Ministry of Agriculture will be responsible for monitoring the following in the South Plain: general suitability of crops for consumption, plant tissue quality (heavy metals, boron and arsenic), contamination of crops by pathogens, crop production, health of livestock, nitrogen, phosphorous and potassium content of soil, fertilizers, manure and sludge, moisture retention properties, $\mathrm{pH}$ and carbon-to-nitrogen ratios in soil.

\subsection{Evidence of connection rates in smaller systems in Tehran}

To estimate the sewage connection rate in Tehran, four zones were selected, and the number of connections within each of them was provided on an annual basis by TSC. The method chosen for analyzing the mentioned data simply deals with calculation of the average accumulative percentage of connections (connection rate) in different years.

\subsection{Summary of environmental impacts}

\section{RESULTS AND DISCUSSION}

The likely direct and indirect environmental impacts of the project are summarized in Table 2 . The impacts are along the lines predicted and are not significant provided that suitable mitigative measures are implemented. Although a number of negative impacts have been predicted, no severe negative impacts are considered likely in the long term. In many cases, predictions cannot be easily made and the implementation, monitoring and effectiveness of mitigative measures will determine the significance of many impacts. The major environmental issues are: (a) the impacts of effluent and sludge from their reuse in agriculture and re-injection of surplus water into groundwater aquifers; and (b) the release of toxic substances (including metals such as cadmium) through industrial discharges. The impacts could be significant without appropriate mitigation measures but not greater than the baseline. The quality of data available will be validated during project implementation [7].

4.2 Major adverse impacts of the project

4.2.1 Effluent quality

The effluent should be of acceptable quality so that it can be used in agriculture and surplus, if any, can be recharged into groundwater. This means that the effluent quality should meet the WHO quality guidelines for use in agriculture and drinking water quality for recharging into groundwater. One of the major parameters of concern is the level of nematodes, which should be less than one egg per liter for water used in agriculture.

\subsubsection{Sludge water}

There is a possibility, given the proposed sludge use application rate and without the planned mitigation measures, that the limit values for cadmium in sludge used in agriculture could be exceeded. Based on the ongoing relocation of industries and the control of industrial discharges into the sewer 
Table 2: Summary of environmental impacts of the Tehran Sewerage Project [7].

\begin{tabular}{|c|c|c|c|}
\hline $\begin{array}{l}\text { Environmental } \\
\text { sector }\end{array}$ & Impact & $\begin{array}{l}\text { Construction } \\
\text { phase }\end{array}$ & $\begin{array}{l}\text { Operational } \\
\text { phase }\end{array}$ \\
\hline \multirow{8}{*}{$\begin{array}{l}\text { Geographical } \\
\text { environment }\end{array}$} & Change of land use & Slight negative & None \\
\hline & Relocation of population & None & None \\
\hline & Disturbance to people & Severe negative & None \\
\hline & Noise & Moderate negative & Insignificant \\
\hline & Vibration & Moderate negative & None \\
\hline & Odor & None & Slight negative \\
\hline & Visual impact & Moderate negative & Insignificant \\
\hline & Impact on traffic and transportation & Severe negative & \\
\hline \multirow{4}{*}{$\begin{array}{l}\text { Social } \\
\text { and economic } \\
\text { environment }\end{array}$} & Impact on population levels & None & Positive \\
\hline & Impact on employment & Positive & Positive \\
\hline & Impact on economy & Positive & Positive \\
\hline & Impact on the indigenous people & Not known & Not known \\
\hline \multirow[t]{2}{*}{$\begin{array}{l}\text { Cultural } \\
\text { environment }\end{array}$} & $\begin{array}{l}\text { Impact on historical and cultural sites } \\
\text { and buildings }\end{array}$ & Slight negative & Positive \\
\hline & Impact on public attitudes & None & None \\
\hline \multirow[t]{7}{*}{ Surface waters } & Sewer connections & None & Positive \\
\hline & Jubes, qanats and canals & None & Positive \\
\hline & Industrial discharges & None & Positive \\
\hline & $\begin{array}{l}\text { Other sewage treatment plants (STPs) } \\
\text { in Tehran }\end{array}$ & Not known & Positive \\
\hline & River water quality & None & Positive \\
\hline & Water supply & None & Positive \\
\hline & Recreational waters & None & None \\
\hline \multirow[t]{4}{*}{ Hydrogeology } & Groundwater movement & None & Positive \\
\hline & Groundwater resources & None & Not known \\
\hline & Groundwater quality & None & Positive \\
\hline & Impact of affluent reuse on Varamin Plain & None & Positive \\
\hline \multirow[t]{8}{*}{ Agriculture } & Crop production & None & Positive \\
\hline & Fertilizer consumption & None & Positive \\
\hline & Soil quality & None & Slight negative \\
\hline & Crop quality & None & Slight negative \\
\hline & Impact on livestock & None & Insignificant \\
\hline & Impact on agricultural practices & None & Positive \\
\hline & Impact on agricultural workers & None & None \\
\hline & Impact on supply of irrigation water & None & Positive \\
\hline \multirow[t]{7}{*}{ Health } & General health impacts & None & Positive \\
\hline & Impact of agricultural use of treated effluent & None & Insignificant \\
\hline & Impact of agricultural use of sewage sludge & None & None \\
\hline & Impact due to chlorination & None & None \\
\hline & Impact due to STP operation & None & None \\
\hline & Impact due to groundwater recharge & None & None \\
\hline & Impact due to pests & None & Insignificant \\
\hline
\end{tabular}


Table 2: Continued

\begin{tabular}{|c|c|c|c|}
\hline $\begin{array}{l}\text { Environmental } \\
\text { sector }\end{array}$ & Impact & $\begin{array}{l}\text { Construction } \\
\text { phase }\end{array}$ & $\begin{array}{l}\text { Operational } \\
\text { phase }\end{array}$ \\
\hline \multirow[t]{2}{*}{ Climate } & Impact on local climate & None & Insignificant \\
\hline & Impact on global climate & None & Insignificant \\
\hline \multirow{4}{*}{$\begin{array}{l}\text { Biological } \\
\text { environment }\end{array}$} & Impact on habitats & Insignificant & Positive \\
\hline & Impact on protected species and habitats & None & Insignificant \\
\hline & Disturbance to fauna & Insignificant & None \\
\hline & $\begin{array}{l}\text { Ecological effects due to improved } \\
\text { surface water quality }\end{array}$ & None & Positive \\
\hline \multirow{5}{*}{$\begin{array}{l}\text { Other } \\
\text { developments }\end{array}$} & Impact of program of industrial relocation & None & None \\
\hline & Impact on green space provision & None & Positive \\
\hline & $\begin{array}{l}\text { Impact on program of improvement } \\
\text { to services in Tehran }\end{array}$ & None & Positive \\
\hline & Impact on water supply schemes & None & Positive \\
\hline & Impact on other STPs & None & Positive \\
\hline
\end{tabular}

system, the levels for toxic substances (including heavy metals such as cadmium) is not expected to exceed the EU and FAO guidelines for the use of sludge in agriculture. Monitoring and assessment of heavy metals in sludge and soils is being undertaken to ensure that limits are not exceeded and allow the formulation of an acceptable sludge reuse strategy.

\subsection{Economic study of the Tehran Sewerage Project}

Tehran city has a constant population of about 8 million that goes beyond 11 million during the daytime, if the population of margin and satellite townships is taken into consideration. The area of the region in which the project is supposed to be implemented in two phases is totally about 32,000 ha. Enjoying an arid climate, the water supply needed for the city is on average about $30 \mathrm{~m}^{3} / \mathrm{s}$, which is provided through an $8,500-\mathrm{km}$ network. The project relies mainly on the subscriber's right fee for sewage. Moreover, selling of treated sewage for agricultural use has also been taken into consideration. A cost-benefit analysis of the project indicates its general commercial profitability. The main inputs for implementation of the project such as electricity, energy, human software and skilled manpower are adequately available. The project's sponsor is the Ministry of Energy and TSC is responsible for connection and receiving of the network and receiving of the subscriber's right fees. Almost all economists consider the problem of calculating the revenue of the project the most basic one. This problem will tend to underestimate the economic value of such projects $[6,10,12]$.

\subsection{Impacts of the project on the national economy and social efficiency}

Among the advantages of the project, the most promising ones may be pointed out as: reduction of different dangerous diseases; weather subtilization due to development of 27,000 ha of irrigating agricultural lands for cultivation of wheat; selling of effluents as an income source, which is very important for Tehran Sewage Organization; creation of new job opportunities in different areas; and related effects in the regional and national economy; etc. This project holds a high priority because it would result in a thriving economy in the region. Since it has numerous beneficial economic 
impacts in terms of its economic returns, the project must be considered as one of the important infrastructures.

According to calculations based on the cost-benefit analysis, the investment return period is proportionate to the net project sources and compensates the construction and operation expenses during the first year. In fact, this index can be considered a breach because the investment return period is at the intersection point of expenses and incomes during a certain financial period. Moreover, because the site of the project is located in the capital city of the country, there is no problem regarding accessibility to experts, transportation of manpower and equipment and other similar problems. Regarding the sensitivity analysis of the project, it is explained that if sound theories concerning the indispensable increment of different activities of the project are considered, the expenses of operation would reduce the increase in benefits with time. In other words, there is an inverse relationship between the volume of activities and the quantity of expenses. Also, there is a direct relationship between the volume of activities and income rate. Thus, in sensitivity analysis there is no limit for diminishing the net present value (NPV) of the project unless it is discontinued, which is almost improbable. Therefore, the feasibility of the project is justified by computation of NPV. Presently, domestic wastewater is discharged into wells, brooks, streams, quantas (local underground water canals) or septic tanks or transferred by tankers to solid waste landfills. This causes the outbreak of different diseases like hepatitis, giardiasis, ascariasis, typhoid and cholera. On the other hand, prevention of water wastage (discharge of water and sewage into groundwater) and its reuse in irrigation will make it possible to develop agricultural lands in the south of Tehran. In any case, it should be mentioned that the Tehran Sewerage Project is a profitable one from the economic, social and national points of view. In the following sections, the project is portrayed based on the different basic aspects of national development (both economic and non-economic) which may not be computable on the basis of monetary parameters (such as computable and non-computable direct impacts). This project is important from the social welfare point of view as no one will be harmed by it (Parto improvement theory) and many shadow prices will be returned to the society through it. Moreover, the cost-benefit analysis of the project indicates it will generate a considerable income with high efficiency. Meanwhile, this project is a profitable development project because after a sound period of commencement of operation, it will result in the generation of suitable revenues in addition to compensating all current and amortization expenses [9].

In terms of the sewerage connection rate estimation, by plotting the average accumulative connection rates versus time, for the three mentioned zones, it was shown that this rate follows an accelerated increase in the first 5-year period while it tends to increase much more slowly thereafter. Therefore, the time period covering the entire data was split into two periods: the first from beginning to the fifth year and the second from the sixth year to the end. The regression fit was realized to be of an exponential type for both the periods. The resulted relationships between the average accumulative connection rate $(Y)$ expressed in percent connected, and time $(t)$ in years, are as follows [9]:

$$
\begin{array}{cc}
Y=9.1437 \mathrm{e}^{(0.407167 t)} & 1 \leq t \leq 5 \\
Y=84.057 \mathrm{e}^{(0.017287 t)} & 6 \leq t \leq 11
\end{array}
$$

The values of $r^{2}$ were $0 / 984$ for eqn (1) and 0.642 for eqn (2).

Based on the regression curve the connection rate in Tehran will be $90 \%$ by the end of the fifth year, that is, $90 \%$ of residents will be connected to Tehran's sewage network. Considering the fact that TSC is the sole authority to permit the residents to connect their household sewage to the implemented sewerage network, it can be predicted that they will inevitably get connected [9]. 


\subsection{Revenue projections}

\subsubsection{Profile of expected connections by expected volumes of water consumption}

Based on the results obtained from the investigation of the number of allocated connections in different zones of Tehran, it is anticipated that $90 \%$ of the created capacity will be purchased by the residents during a 5-year period (Fig. 2). Also, it is predicted that 5\% of the created capacity in each year will be allocated in the next year (first year), and 30\%, 20\%, 20\% and 15\% of the mentioned capacity will be allocated within the next 4 years, respectively. Therefore, by the end of the fifth year, $90 \%$ of the capacity will be connected to the system. About $10 \%$ of the total created capacity will not be capable of being connected to the system, due to some technical or implementation problems or unwillingness to connect. Therefore, the number of established connections in each year was determined covering a period ending in 2015 (when the anticipated capacity will be met), and it was assumed to be constant from 2015. The results of the data analysis show a capita of 4.8 people per connection. In addition, the household water consumption is 142 liters/capita/day based on the studies conducted by consulting engineers. Therefore, the volume of annual water consumption (the consumption related to households) is predictable. Also, the volume of water consumption related to other consumers was determined as 56 liters/capita/day [10].

4.6 Investment costs and operation costs

4.6.1 Execution costs of the system

The execution cost of the project is estimated to amount to over 15,000 billion rials during a 25 -year period ( 1 US $\$=10,000$ rials).

4.6.2 Operation and maintenance costs of the system

By studying the costs of existing small regional systems in Tehran and comparing them to larger ones (e.g. Isfahan Sewage System), the per capita costs of operation was found to be very high due

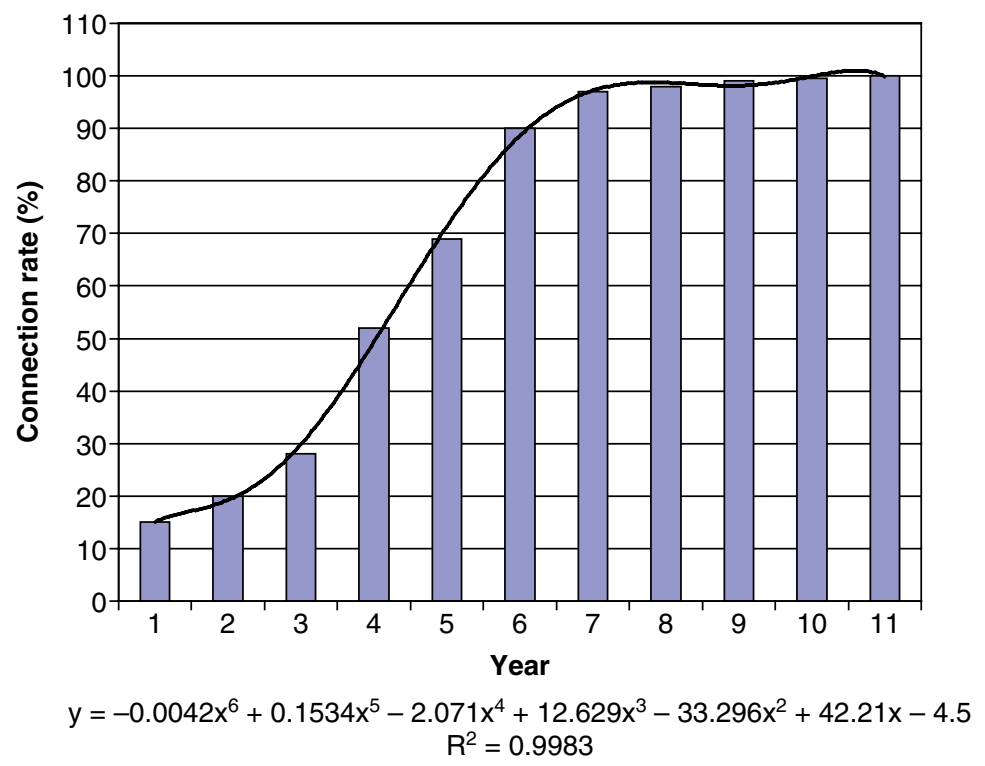

Figure 2: Observed and estimated values of average connection rate [10]. 
to the small size of such systems. Thus, the data from the Isfahan Sewage System (which can be considered similar to that of Tehran) was used to determine the operation costs of the Tehran Sewerage Project. The total operation and maintenance costs of Tehran's sewage system is approximately US\$ 250 million and the amount for payment of wages is approximately US\$ 51 million (from 1999 to 2028) [6].

4.6.3 Distribution of incomes from the sale of water and sludge

The total distribution of incomes from the sale of water is approximately US\$ 400 million (from 1999 to 2028). The total benefit obtained by selling treated sludge as fertilizer for the first phase of the treatment plant will be approximately US\$900,000 [6].

4.7 Anticipated increase in agricultural output attributable to the project and incremental land usage by year

The increase in the land area under cultivation is exactly proportional to the volume of the produced effluent. The annual rate of wastewater production can be determined based on the number of connections established each year and the wastewater production capacity of 214 liters/capita/day. However, in case of agricultural usage, the volume of treated wastewater (effluent) is considered as the basis of determination. The annual amount of effluent production for a 30 -year period is shown in Fig. 3. The total agricultural benefit is approximately US\$ 900 million (from 1999 to 2028) (Fig. 4) [10].

\subsection{Study of non-qualified impacts}

Undoubtedly, the implementation of the Tehran Sewerage Project will entail some adverse and even beneficial impacts that cannot be described in defined qualitative and quantitative frameworks. Hence, due attention should be paid to these impacts while analyzing economic, social and cultural

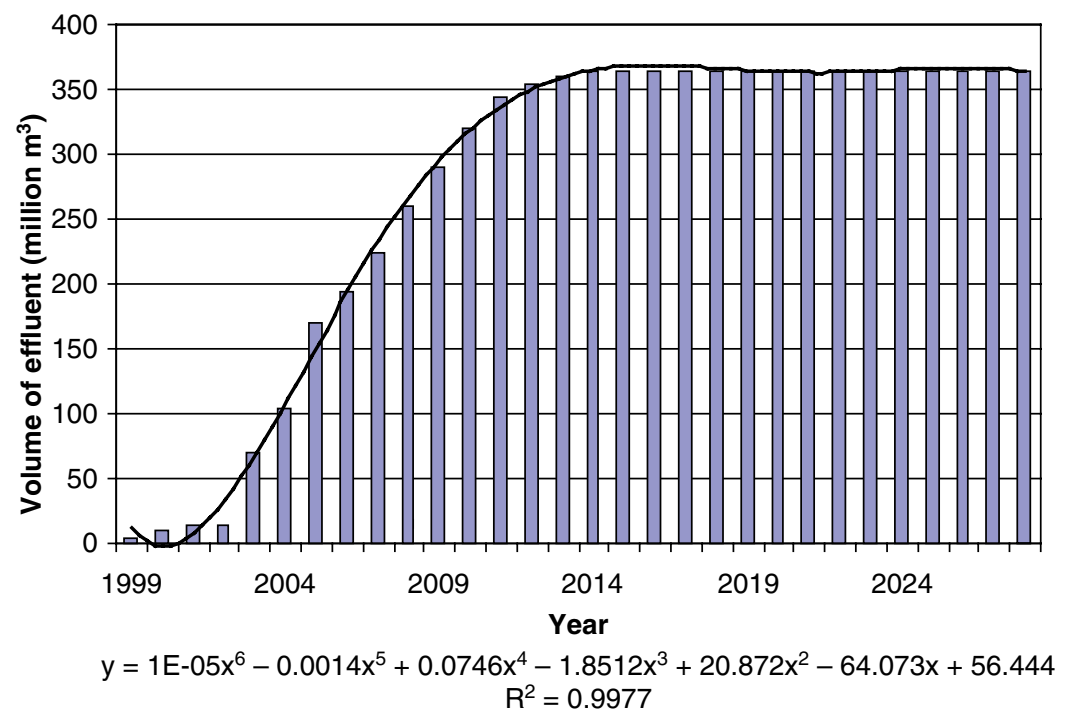

Figure 3: The annual amount of effluent production [13]. 


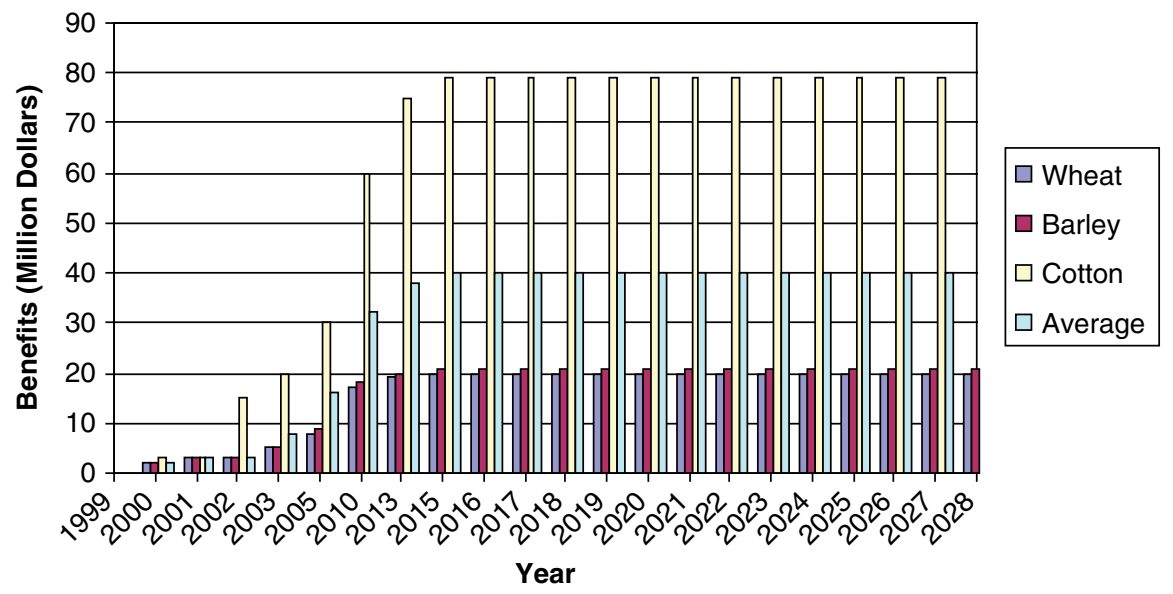

Figure 4: Agricultural benefits [13].

aspects of the project. The non-qualified impacts are the expansion of research activities, expansion of public services, preventing emigration of villagers, reduction of side environmental pollution, optimizing water demand management, improvement of groundwater quality, improvement of existing food chain conditions, improvement of agriculture soil quality and reduction of competition for agricultural, industrial and urban water consumption [10].

\subsection{Life cycle processes of TSC and financing plan of the project}

One of the basic problems facing the Tehran Sewerage Project is the timely provision of financial resources (Figs. 5 and 6). Long delays in implementation of this project have had an adverse effect on the situation. Therefore, time and speed factors having an overall effect on the various aspects of the project could play a vital role in its successful implementation. The following points constitute the most important factors in the fulfillment of this infrastructural project.

Creation of incentives for citizens to take an active participation in the project by paying a part of the cost by way of subscriptions; preparation of a proper execution schedule compatible with the cash inflow; creating a balance between the amount of subscription rights and increase in costs due to inflation; creation of fresh financial and earning resources with a view to prevent suspension of the project's execution; formulation and approval of rational tariffs consistent with the capital investment and the economic status of citizens; stability of management, rules, regulations and the national belief as well as utilization of the latest technology and know-how; complete coordination and support of organizations concerned with urban services. As a result of efforts taken by the Ministry of Energy, a loan to the amount of US\$ 145 million has been provided by the World Bank to be paid towards a part of the project cost on the basis of the agreement exchanged $[11,14]$.

\section{CONCLUSION}

Tehran covers an area of more than 70,000 ha; its population has increased far beyond previous expectations leading to rapid expansion in the past few years. This has resulted in a rapid increase in the amount of water consumed and hence the generated wastewater which requires proper removal and treatment. This has prompted TSC to request assistance from the World Bank in securing loans 


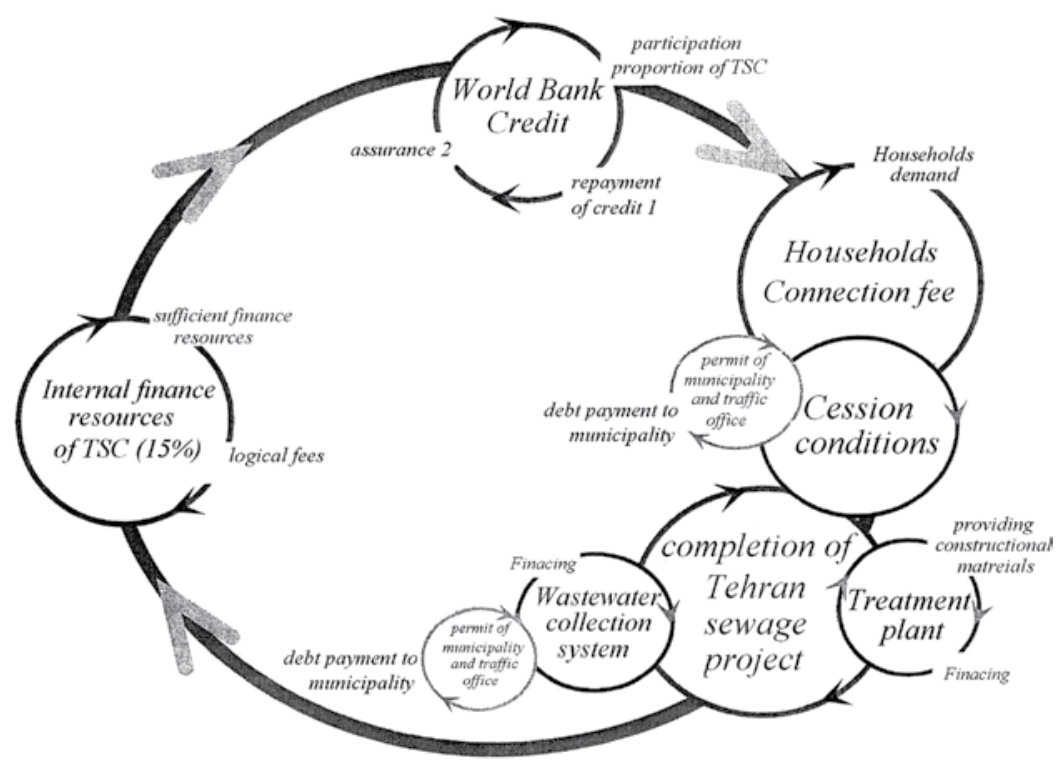

Figure 5: Life cycle processes of TSC [11].

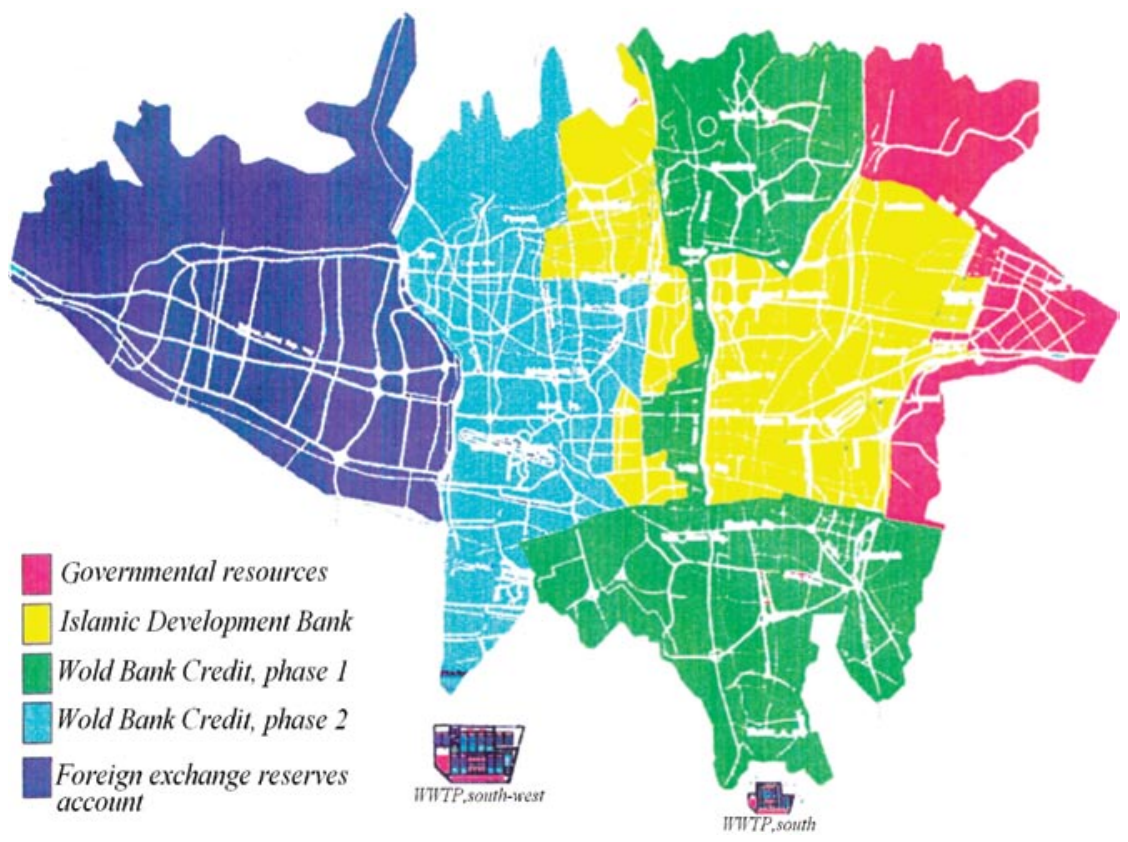

Figure 6: Finance apportionment for different sections of the Tehran Sewerage Project [11]. 
and also look at the possibility for public-private participation. Environmental assessment is required since the project may be associated with diverse and significant environmental impacts during the construction and operation phases. By the construction of this project, considerable problems concerning health aspects and diseases will be reduced, new agricultural lands will be developed, new job opportunities will be created, wastage of water will be prevented and the sound use of water will result in more productivity in different sectors. Almost $70 \%$ of the expenses of this project will be returned via subscriber's fees. From Economic Rate of Return (ERR) point of view, more than $300 \%$ holds indirect and side incomes, by implementation of the sewerage project. Consequently, reimbursement of debts will be possible. The project is profitable even with the calculation of a related interest rate and it is one of those projects which are highly supported both by the people and by the government.

\section{REFERENCES}

[1] Transport and Road Research Laboratory, The Design of Urban Sewer Systems - Research into the Relation Between the Rate of Rainfall and the Rate of Flow in Sewers, 1962.

[2] Bartlett, R.E., Public Health Engineering, Sewerage, Applied Science Publishers Ltd: London, 2005.

[3] SCI, Annual Report of Data, Statistical centre of Iran, 2006.

[4] IRIMO, Climate of Tehran, Iran Meteorological Organization, 2009.

[5] Badalians Gholikandi, G., Public-Private Partnership for Infrastructure Development of Water and Power Industry, Based on BOT Method, Nopardazan: Tehran, 2002.

[6] Dervis, K., Sud, I.K., Villiard, J.C., Saghir, J. \& Benouahi, M., Project Appraisal Document on a Proposed Loan in the Amount of US \$145.0 Million to the Islamic Republic of Iran for a Tehran Sewerage Project, Tehran, World Bank, 2000.

[7] TSC, Tehran Sewerage Project: Environmental Assessment, Tehran Sewerage Company (TSC)-Ministry of Energy, 1999.

[8] Ray Ab, Environmental Monitoring and Auditing of Tehran Sewage Project, Ray Ab Consulting Engineers: Tehran, 1999.

[9] Mahab Ghods, Economical, Environmental and Social Impact of Tehran Sewage Project, Mahab Ghods Consulting Engineers: Tehran, 2005.

[10] Ray Ab, Economic Study of Tehran Sewage Project, Ray Ab Consulting Engineers: Tehran, 1999.

[11] TSC, Technical Administration, Economic of Tehran sewage project, Tehran Sewage Company (TSC): Tehran, 2007.

[12] Badalians Gholikandi, G. \& Esmaili Keshteli, F., Financing of Wastewater Projects from Non-governmental Resources, Tehran, Power and Water University of Technology, 2004.

[13] Rahyab, Environmental and Social Impact Assessment Study (phase 2) of Tehran Sewage Project, Rahyab Project Management and Engineering Consultants: Tehran, 2006.

[14] Badalians Gholikandi, G., Urumie, H.R., Riahi, R. \& Keshteli, M.B., Wastewater project of Tehran: development, challenges and chances. Sustainable Development and Planning 2009, Fourth International Conference, WIT: Cyprus, 2009. 